\title{
Analysis of the gap in PCR monitoring availability for patients with chronic myeloid leukemia in 60 low- and middle-income countries
}

\author{
Seth Rowley ${ }^{1}$, Pat Garcia-Gonzalez², Jerald P. Radich³, Ann Kim Novakowski², Irina Usherenko² \\ and Joseph B. Babigumira ${ }^{4,5^{*}}$ (D)
}

\begin{abstract}
Purpose: To estimate the resource gap in the polymerase chain reaction (PCR) monitoring for patients with chronic myeloid leukemia (CML) in low- and middle-income countries (LMICs).

Methods: We developed a model of demand and supply of PCR monitoring of CML patients in 60 LMICS. PCR testing was assumed to use Cepheid's GeneXpert ${ }^{\circledR}$ IV system. We included costs of GeneXpert ${ }^{\circledR}$ instruments, uninterrupted power supplies, warranties, calibration kits, test cartridges, and shipping. We calculated the country-specific monetary gap in PCR monitoring, stratified by country priority defined as the availability of tyrosine kinase inhibitors (TKIs) through The Max Foundation initiatives.

Results: The 5-year gap in PCR monitoring was $\$ 29.1$ million across all countries, 22\% (\$6.4 million) in countries with all five TKIs available, 20\% (\$5.7 million) in countries with four TKIs available, 50\% (\$14.5 million) in countries with three TKIs available, $8 \%$ ( $\$ 2.2$ million) in countries with two TKIs available, and $1 \%$ (\$0.3 million) in countries with one TKI available. The gap was highest in South Asia (52\%; 15.1 million) and lowest in Latin America (6\%; \$1.9 million). Excluding labor costs, the bulk of the resource needs (86\%; $\$ 25.2$ million) were for procurement of BCR-ABL cartridges.

Conclusion: Removing the 5-year gap in PCR monitoring capacity for CML in LMICs will require the mobilization of significant resources and will likely lead to better treatment outcomes and reduced treatment costs through optimization of treatment, discontinuation of therapy in appropriate patients, and facilitation of clinical research. Development of streamlined monitoring guidelines for resource-limited countries should be considered.
\end{abstract}

\section{Background}

The advent of tyrosine kinase inhibitors (TKIs) has transformed chronic myeloid leukemia (CML) from a near universally fatal disease into a chronic condition. There are now five TKIs approved for use in newly diagnosed CML in the USA, the pioneering TKI imatinib, and the

*Correspondence: jobabigumira@gmail.com

${ }^{4}$ Global Medicines Program, Department of Global Health, School of Public Health, University of Washington, Seattle, USA

Full list of author information is available at the end of the article "second generation" TKIs dasatinib, nilotinib, ponatinib, and bosutinib. All have similarly impressive results and CML patients now experience life expectancy near that of the age matched general population [1].

CML is caused by the genetic juxtaposition of the $\mathrm{BCR}$ gene from chromosome 22 with the tyrosine kinase domains of the ABL gene from chromosome 9. This unique gene fusion creates the fusion BCR-ABL1 mRNA, which is the target for polymerase chain reaction (PCR) diagnostic and monitoring assays. The protein product of

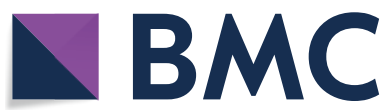

(c) The Author(s) 2021. This article is licensed under a Creative Commons Attribution 4.0 International License, which permits use, sharing, adaptation, distribution and reproduction in any medium or format, as long as you give appropriate credit to the original author(s) and the source, provide a link to the Creative Commons licence, and indicate if changes were made. The images or other third party material in this article are included in the article's Creative Commons licence, unless indicated otherwise in a credit line to the material. If material is not included in the article's Creative Commons licence and your intended use is not permitted by statutory regulation or exceeds the permitted use, you will need to obtain permission directly from the copyright holder. To view a copy of this licence, visit http://creativecommons.org/licenses/by/4.0/. The Creative Commons Public Domain Dedication waiver (http://creativecommons.org/publicdomain/zero/1.0/) applies to the data made available in this article, unless otherwise stated in a credit line to the data. 
BCR-ABL translocation drives the pathogenesis of CML and is the target of the TKIs.

Peripheral blood can be used for BCR-ABL monitoring, rather than bone marrow, and guidelines of the European Leukemia Network (ELN) and the National Cancer Care Network (NCCN) include frequent monitoring as a way to track response. In general, both guidelines call for every 3-month peripheral blood PCR testing for BCRABL1 [2, 3]. Treatment milestones, including changing TKIs for resistance, or discontinuation of TKIs after a durable deep response, are based on the BCR-ABL1 monitoring.

Conventional PCR testing is complicated and labor intensive, demanding trained personnel, many chemicals, and expensive equipment. Quality control is essential to obtain and maintain proper sensitivity and specificity of the assay, and this requires technical and methodological expertise and training. The GeneXpert system from Cepheid is a cartridge-based system that requires minimal hands on sample preparation and is ideal for point of care, real-time assays [4]. The system has a multiple modular design that can run cartridges for multiple diseases including infections and cancer. The assay for BCRABL1 was developed in collaboration with U.S. academic centers and is now used in many centers in the U.S. and Europe for CML monitoring in clinical trials and community settings, and is FDA approved in the U.S. The system is widely used in low- and middle-income countries (LMICs) for infectious diseases (e.g., TB, HIV) and utilization is increasing in a handful of oncology applications including BCR-ABL1 $[5,6]$. The Cepheid platform has many desired features in the LMIC setting, including ease and efficiency of use (less technical training needed, with flexible use between batches or single assays), easy shipping solutions (cartridges rather than many different reagent supplies), high reproducibility, and reliable precision and accuracy.

To bring TKIs to LMICs, The Max Foundation partnered with Novartis to launch the Glivec ${ }^{\circledR}$ International Patient Assistance Program (GIPAP), an innovative access model that made Novartis' breakthrough oral TKI therapy, Glivec ${ }^{\circledR}$ (imatinib) available to patients at no cost. Glivec was made available to patients in selected LMICs around the world who met specific program criteria, such as confirmed indication for the medication, presence of partner institutions for diagnosis and management, and tax waivers for donated TKIs by governments among other criteria [7]. The Max Foundation administered the program, working closely with a global network of more than 1500 trained physicians in 80 LMICs [7].

In the early years of the program, BCR-ABL1 testing was largely performed by shipping blood to outside centers, a procedure that was costly, time-consuming, and inherently unscalable. Recognizing the critically important role that point-of-care systems play in the diagnosis and monitoring of patients in resource poor settings, The Max Foundation developed a collaboration with Cepheid to increase access to instruments and tests in more than 60 LMICs. Cepheid provided the GeneXpert $^{\circledR}$ System and Xpert ${ }^{\circledR}$ BCR-ABL Monitor Assays (through The Max Foundation) to public sector end users at a preferential price in order to decrease barriers to access due to cost. The dramatic increases in monitoring meant disease resistance could be detected, so that TKI options to treat resistance could be initiated as needed. The Max Foundation began partnering with four other leading pharmaceutical companies to bridge access to all five TKIs available on the market for the treatment of CML today. As a result of these efforts, selected patients in thirty of the world's lowest income economies have access to all available treatment options through The Max Foundation's Max Access Solutions.

Recently, GIPAP evolved into a new partnership model between Novartis and The Max Foundation, CMLPath to Care $^{\mathrm{TM}}$. CMLPath to Care ${ }^{\mathrm{TM}}$ differs from the GIPAP program in that The Max Foundation assumes from Novartis the responsibility for delivering treatment to patients. The Max Foundation, under the umbrella of Max Access Solutions (MAS), manages the entire supply chain, while strengthening interactions with local stakeholders and providing hands-on, local patient support [8].

The establishment of collaborations with developers of all TKIs for the treatment of CML enables The Max Foundation to respond to health care providers' requests for second and third line treatment in many of the lowest income economies in the world. Yet, despite the preferential pricing available for Cepheid products, access to PCR remains one of the most pervasive barriers to achieving optimal clinical outcomes. Without adequate monitoring, physicians are unable to make timely and appropriate clinical decisions that help patients with CML achieve a deep response to available treatments. This analysis was performed to assess the resources needed to close the 5-year gap in PCR monitoring capacity for CML patients covered by programs supported by the Max Foundation in countries where The Max Foundation currently operates.

\section{Methods}

\section{Analytic overview}

We developed a Microsoft Excel-based demand, supply, and forecast model for the monitoring of CML patients in a selected group of countries and a selected group of patients in those countries covered by access initiatives and using preferential prices available through The Max 
Foundation for the GeneXpert ${ }^{\circledR}$ system. The gap in PCR capacity for monitoring was estimated as the difference between current/projected demand and current/projected supply over a 5-year time horizon from 2017 to 2021.

We estimated effective demand as the number of patients that would qualify for access to imatinib treatment in each country i.e. patients who would qualify for treatment under The Max Foundation's access initiatives. This is differentiated from actual demand based on the burden of CML in each country, a burden that is substantially higher than is covered by The Max Foundation's access initiatives [9]. We estimated supply as the number of patients that are able to access at least 3 PCR tests per year, in line with monitoring recommendations $[2,3]$. We included an additional 0.5 tests per individual per year to account for off-label use of the Xpert ${ }^{\circledR}$ cartridges for diagnostic purposes, as we are aware that physicians in resource poor settings may utilize the cartridges to confirm presence of BCR-ABL, thereby meeting medical eligibility requirements for treatment access. Therefore, the supply estimate was based on the number of patients able to access 3.5 tests per year.

Countries were categorized for the analysis by availability of one or more of the five TKIs to maximize the potential utility of PCR monitoring results by physicians. Countries were excluded from the analysis if they were known to have appropriate access to PCR and if they did not have preferential pricing for GeneXpert PCR through Cepheid.

\section{Demand estimation}

We estimated future demand for PCR monitoring in The Max Foundation programs based on historical patient data from The Max Foundation. We restricted our demand estimates to patients who would qualify for Max Access Solutions and The Max Foundation's preferential pricing agreement with Cepheid. Of the 67 countries covered by Max Access Solutions and The Max Foundation's preferential pricing agreement with Cepheid, 56 had 12 years of historical data, four countries had 11 years of historical data, two countries had 10 years of historical data, three countries had 8 years of historical data, one country had 7 years of historical data, and one country had 4 years of historical data. In our final analysis, we included 60 countries after excluding Angola, Barbados, Botswana, Costa Rica, Guinea, Pakistan, and Panama because they did not have patients currently receiving treatment through The Max Foundation programs. For countries with non-linear historical trends, the earlier, nonlinear years were truncated from the analysis. Estimates of future demand, estimated as number of patients, were calculated using a simple linear ordinaryleast-squares regression.

Data from The Max Foundation demonstrate that the introduction of GeneXpert ${ }^{\circledR}$ affects the demand for CML treatment, and consequently, the demand for PCR monitoring in a country. Therefore, based on consensus among the study team members, we made the assumption and modeled that the rate of growth doubled $(2 x)$ after introduction of GeneXpert ${ }^{\circledR}$, e.g., a country that historically gained 10 additional patients per year before GeneXpert ${ }^{\circledR}$ introduction, was modeled, after introduction, as gaining 20 additional patients per year.

\section{Estimation of the gap in PCR monitoring capacity}

The quantity of required GeneXpert ${ }^{\circledR}$ instruments and GeneXpert ${ }^{\circledR}$ cartridges for purposes of gap estimation was based on a number of factors: current demand, anticipated future demand, current number of GeneXpert $^{\circledR}$ instruments in place by country, geographic demand distribution of patients and testing facilities, and expert opinion in the form of NCCN and ELN guidelines, as described above.

\section{Costs}

We estimated the following PCR monitoring-related costs in year 1: (1) GeneXpert ${ }^{\circledR}$ instruments, (2) uninterrupted power supplies (UPS), (3) warranties, (4) calibration kits, (5) test cartridges, and (6) shipping for instruments and test cartridges. During years two to five, the following PCR monitoring-related costs were included: (1) calibration kits, (2) test cartridges, and (3) shipping costs for cartridges. Costs did not include labor to perform the assay. Costs were obtained from The Max Foundation records and estimated in 2017 \$US. Future costs were discounted to 2017 \$US at a rate of $3 \%$.

Our analysis differentiated between fixed costs in the first year (GeneXpert ${ }^{\circledR}$ instruments, UPSs, and instrument warranty) and variable costs (cartridges, shipping, and calibration). Costs for the instruments, warranty, calibration kits, and UPSs, were established by contract (see Table 1). Shipping costs were based on per-country historical shipping data when available and based on a global average when unavailable. Calibration kits are required every 2000 tests, or once per year, whichever occurs first. Instruments have a factory warranty of 2 years; additional warranty costs are included in the model for years three through five.

\section{Credibility Intervals}

We constructed credibility intervals for the mean total 5-year gap cost for each country by iteratively drawing single values from a normal distribution for each component cost element (e.g. GeneXpert ${ }^{\circledR}$ cartridges), 
Table 1 Cost parameters*

\begin{tabular}{|c|c|c|c|c|}
\hline \multirow[t]{2}{*}{ Variable } & \multirow[t]{2}{*}{ Base Value } & \multicolumn{3}{|c|}{ Normal distribution values } \\
\hline & & Mean & Lower & Upper \\
\hline Glivec pills (per year) & 365 & 365 & 182.5 & 547.5 \\
\hline Patient visits per year & 3.5 & 3.5 & 1.75 & 5.25 \\
\hline GeneXpert ${ }^{\circledR}$ & $\$ 17,000$ & $\$ 17,000$ & $\$ 17,000$ & $\$ 17,000$ \\
\hline Uninterrupted Power Supply & $\$ 780$ & $\$ 780$ & $\$ 390$ & $\$ 1,170$ \\
\hline GeneXpert ${ }^{\circledR}$ cartridges & $\$ 50$ & $\$ 50$ & $\$ 25$ & $\$ 75$ \\
\hline GeneXpert ${ }^{\circledR}$ warranty (yrs. 3-5) & $\$ 2,900$ & $\$ 2,900$ & $\$ 1,450$ & $\$ 4,350$ \\
\hline GeneXpert ${ }^{\circledR}$ calibration kit & $\$ 450$ & $\$ 450$ & $\$ 225$ & $\$ 675$ \\
\hline Annual Patient Growth Rate & $2 x$ & $2 x$ & $1 x$ & $3 x$ \\
\hline
\end{tabular}

* All cost data were obtained from The Max Foundation records

${ }^{*}$ As a consequence of increased access to PCR monitoring using GeneXpert ${ }^{\circledR}$

calculating the resulting mean of many draws, and then summing each component average into an overall cost for each country for each year. The means of the normal distributions from which we drew were set equal to the deterministic cost values. The upper and lower 95\% intervals were set to $\pm 50 \%$ of the means. The presented estimates were derived from 1,000 iterations.

\section{Results}

The total 5-year gap in PCR monitoring capacity for each country, categorized by TKI access, is presented in Table 2. Over the 5-year period, the estimated gap in PCR monitoring capacity was $\$ 29,143,083$ across all countries covered by access initiatives. Over the 5 -year period, due to the combination of country-specific trends and anticipated patient increases due to improved access to PCR testing, the patient population was estimated to grow from 26,915 patients to 30,071 patients at year-end 2021.

The distribution of the total PCR monitoring capacity gap by TKI access level (Table 3 ) was as follows: $22.09 \%(\$ 6,438,176)$ in countries with all five TKIs, $19.64 \%(\$ 5,723,011)$ in countries with four TKIs, $49.73 \%$ $(\$ 14,493,223)$ in countries with three TKIs, $7.64 \%$ $(\$ 2,227,083)$ in countries with two TKIs, and $0.90 \%$ $(\$ 261,590)$ in countries with one TKI.

In those countries where all five TKIs are currently available through The Max Foundation programs, the 5 -year gap ranged from $\$ 31,681$ in Sierra Leone to $\$ 1,561,298$ in Nepal. In the countries with four TKIs available, the gap ranged from $\$ 29,515$ in Central Africa Republic to $\$ 1,363,279$ in Sudan. In the countries with three TKIs available, the gap ranged from $\$ 31,144$ in Seychelles to $\$ 13,238,674$ in India. In the countries with two TKIs available, the gap ranged from $\$ 35,980$ in The Bahamas to $\$ 1,422,762$ in Vietnam. In the countries with a single TKI available through Max programs, the gap ranged from \$36,238 in Ecuador to \$68,943 in Gabon.

The distribution of the total PCR monitoring capacity gap by region was as follows (Table 3$): 52 \%(\$ 15,084,618)$ in South Asia, $25 \%(\$ 7,284,210)$ in Africa/Middle East, $10 \%(\$ 2,954,959)$ in Europe/Central Asia, $7 \%(\$ 1,938,714)$ in Asia Pacific, and 6\% $(\$ 1,880,582)$ in Latin America. India alone accounted for $45 \%(\$ 13,238,674)$ of the total gap.

The distribution of the total PCR monitoring capacity gap by resource was as follows: $86 \%(\$ 25,203,261)$ for cartridges, $7 \%(\$ 2,014,202)$ for shipping, $3 \%(\$ 1,020,000)$ for GeneXpert ${ }^{\circledR}$ machines, $2 \%(\$ 522,000)$ for warranties, $1 \%(\$ 336,820)$ for calibration kits, and $0.2 \%(\$ 46,800)$ for UPSs (Fig. 1).

Across the countries where The Max Foundation's is involved, the negotiated purchase agreements with Cepheid result in a nominal cumulative cost reduction of $\$ 1,246,667$ as compared with GeneXpert IV machine market pricing levels, and additional cost reductions of $\$ 30,747,979$ for GeneXpert cartridges, as compared with average market prices.

\section{Discussion}

We estimated the gap in PCR monitoring capacity for CML patients in countries covered by access initiatives available through The Max Foundation. Over a 5-year period, the total gap in PCR monitoring capacity amounts to approximately $\$ 30$ million, including instrument and cartridge subsidies. This estimate corresponds to the cost of monitoring patients with CML every 3 months over a 5-year period, categorized by access to TKIs. Approximately one-fifth of the total gap in PCR monitoring capacity is in countries with access to all five TKIs through the Max Access Solutions current portfolio. One-third of the gap is in countries with access to four out of five TKIs.

There was substantial variability in the country-specific estimates of the gap in PCR monitoring capacity, based largely on the number of patients needing testing. The overall range was from $\$ 29,515$ in Central African Republic to $\$ 13.2$ million in India where more than $50 \%$ of The Max Foundation's total CML patient population is treated. It would be worthwhile to apply, in addition to a TKI-access-based prioritization scheme, a prioritization scheme on a country-by-country basis to ensure that countries with GeneXpert ${ }^{\circledR}$ instruments have the resources to procure cartridges in the short- and medium-term.

Given that GeneXpert ${ }^{\circledR}$ cartridges and GeneXpert $^{\circledR}$ instruments are linked resources, it is preferable to take a pragmatic approach and examine access on the basis of potential utility. For example, procuring GeneXpert ${ }^{\circledR}$ 
Table 2 Total 5-year gap

\begin{tabular}{|c|c|c|c|c|}
\hline Country & Region & TKIs & Total 5-year Gap & $95 \% \mathrm{Cl}$ \\
\hline Benin & Africa/Middle East & 5 & $\$ 88,758$ & $\$ 86,510$ to $\$ 89,150$ \\
\hline Bhutan & Asia Pacific & 5 & $\$ 49,031$ & $\$ 48,250$ to $\$ 49,160$ \\
\hline Burkina Faso & Africa/Middle East & 5 & $\$ 92,401$ & $\$ 90,060$ to $\$ 92,870$ \\
\hline Cambodia & Asia Pacific & 5 & $\$ 108,594$ & $\$ 104,680$ to $\$ 109,390$ \\
\hline East Timor & Asia Pacific & 5 & $\$ 36,976$ & $\$ 36,590$ to $\$ 37,050$ \\
\hline Ghana & Africa/Middle East & 5 & $\$ 200,603$ & $\$ 192,860$ to $\$ 201,580$ \\
\hline Haiti & Latin America (LATAM) & 5 & $\$ 50,842$ & $\$ 50,040$ to $\$ 51,040$ \\
\hline Honduras & Latin America (LATAM) & 5 & $\$ 284,589$ & $\$ 273,850$ to $\$ 286,210$ \\
\hline Kyrgyzstan & Europe/Central Asia & 5 & $\$ 272,886$ & $\$ 263,750$ to $\$ 274,330$ \\
\hline Madagascar & Africa/Middle East & 5 & $\$ 98,186$ & $\$ 95,700$ to $\$ 98,750$ \\
\hline Malawi & Africa/Middle East & 5 & $\$ 70,677$ & $\$ 69,080$ to $\$ 71,040$ \\
\hline Moldova & Europe/Central Asia & 5 & $\$ 162,785$ & $\$ 157,760$ to $\$ 163,700$ \\
\hline Mongolia & Europe/Central Asia & 5 & $\$ 123,690$ & $\$ 119,890$ to $\$ 124,130$ \\
\hline Nepal & South Asia & 5 & $\$ 1,561,298$ & $\$ 1,506,040$ to $\$ 1,571,720$ \\
\hline Nicaragua & Latin America (LATAM) & 5 & $\$ 161,998$ & $\$ 157,000$ to $\$ 162,790$ \\
\hline Niger & Africa/Middle East & 5 & $\$ 58,210$ & $\$ 57,040$ to $\$ 58,370$ \\
\hline Nigeria & Africa/Middle East & 5 & $\$ 1,173,867$ & $\$ 1,131,180$ to $\$ 1,183,210$ \\
\hline Papua New Guinea & Asia Pacific & 5 & $\$ 90,538$ & $\$ 88,360$ to $\$ 91,170$ \\
\hline Republic of Congo & Africa/Middle East & 5 & $\$ 93,545$ & $\$ 91,130$ to $\$ 93,990$ \\
\hline Rwanda & Africa/Middle East & 5 & $\$ 102,710$ & $\$ 98,830$ to $\$ 103,250$ \\
\hline Sierra Leone & Africa/Middle East & 5 & $\$ 31,681$ & $\$ 31,490$ to $\$ 31,830$ \\
\hline Tajikistan & Europe/Central Asia & 5 & $\$ 73,353$ & $\$ 71,290$ to $\$ 73,330$ \\
\hline Togo & Africa/Middle East & 5 & $\$ 65,240$ & $\$ 63,630$ to $\$ 65,460$ \\
\hline Uzbekistan & Europe/Central Asia & 5 & $\$ 1,385,716$ & $\$ 1,336,100$ to $\$ 1,395,670$ \\
\hline Cameroon & Africa/Middle East & 4 & $\$ 164,268$ & $\$ 159,150$ to $\$ 165,090$ \\
\hline Central Africa Republic & Africa/Middle East & 4 & $\$ 29,515$ & $\$ 29,210$ to $\$ 29,530$ \\
\hline Cote d'Ivoire & Africa/Middle East & 4 & $\$ 207,340$ & $\$ 200,920$ to $\$ 208,790$ \\
\hline Democratic Republic of Congo & Africa/Middle East & 4 & $\$ 40,534$ & $\$ 40,100$ to $\$ 40,700$ \\
\hline Ethiopia & Africa/Middle East & 4 & $\$ 964,173$ & $\$ 926,070$ to $\$ 969,910$ \\
\hline Georgia & Europe/Central Asia & 4 & $\$ 375,196$ & $\$ 362,310$ to $\$ 377,190$ \\
\hline Kenya & Africa/Middle East & 4 & $\$ 1,102,988$ & $\$ 1,063,540$ to $\$ 1,110,340$ \\
\hline Mali & Africa/Middle East & 4 & $\$ 129,666$ & $\$ 125,850$ to $\$ 130,250$ \\
\hline Philippines & Asia Pacific & 4 & $\$ 177,153$ & $\$ 172,700$ to $\$ 178,080$ \\
\hline Senegal & Africa/Middle East & 4 & $\$ 247,913$ & $\$ 238,460$ to $\$ 249,220$ \\
\hline Sri Lanka & South Asia & 4 & $\$ 284,646$ & $\$ 273,970$ to $\$ 286,080$ \\
\hline Sudan & Africa/Middle East & 4 & $\$ 1,363,279$ & $\$ 1,313,480$ to $\$ 1,371,390$ \\
\hline Tanzania & Africa/Middle East & 4 & $\$ 197,892$ & $\$ 191,470$ to $\$ 199,000$ \\
\hline Uganda & Africa/Middle East & 4 & $\$ 339,760$ & $\$ 328,270$ to $\$ 341,910$ \\
\hline Zambia & Africa/Middle East & 4 & $\$ 98,688$ & $\$ 95,950$ to $\$ 99,020$ \\
\hline Bolivia & Latin America (LATAM) & 3 & $\$ 302,636$ & $\$ 293,390$ to $\$ 304,270$ \\
\hline El Salvador & Latin America (LATAM) & 3 & $\$ 210,811$ & $\$ 203,830$ to $\$ 211,630$ \\
\hline Guatemala & Latin America (LATAM) & 3 & $\$ 339,146$ & $\$ 327,800$ to $\$ 341,310$ \\
\hline India & South Asia & 3 & $\$ 13,238,674$ & $\$ 12,849,210$ to $\$ 13,457,480$ \\
\hline Paraguay & Latin America (LATAM) & 3 & $\$ 146,770$ & $\$ 142,670$ to $\$ 147,700$ \\
\hline Seychelles & Africa/Middle East & 3 & $\$ 31,144$ & $\$ 30,960$ to $\$ 31,290$ \\
\hline Surinam & Latin America (LATAM) & 3 & $\$ 51,723$ & $\$ 50,890$ to $\$ 51,920$ \\
\hline Zimbabwe & Africa/Middle East & 3 & $\$ 172,320$ & $\$ 166,040$ to $\$ 173,410$ \\
\hline Azerbaijan & Europe/Central Asia & 2 & $\$ 476,120$ & $\$ 461,130$ to $\$ 481,150$ \\
\hline Bahamas & Latin America (LATAM) & 2 & $\$ 35,980$ & $\$ 35,690$ to $\$ 36,110$ \\
\hline
\end{tabular}


Table 2 (continued)

\begin{tabular}{|c|c|c|c|c|}
\hline Country & Region & TKls & Total 5-year Gap & $95 \% \mathrm{Cl}$ \\
\hline Belarus & Europe/Central Asia & 2 & $\$ 47,129$ & $\$ 46,400$ to $\$ 47,220$ \\
\hline Fiji & Asia Pacific & 2 & $\$ 53,660$ & $\$ 52,710$ to $\$ 53,820$ \\
\hline Jamaica & Latin America (LATAM) & 2 & $\$ 112,265$ & $\$ 109,310$ to $\$ 112,920$ \\
\hline Kazakhstan & Europe/Central Asia & 2 & $\$ 38,083$ & $\$ 39,390$ to $\$ 40,380$ \\
\hline Saint Lucia & Latin America (LATAM) & 2 & $\$ 41,084$ & $\$ 40,650$ to $\$ 41,270$ \\
\hline Vietnam & Asia Pacific & 2 & $\$ 1,422,762$ & $\$ 1,372,220$ to $\$ 1,435,050$ \\
\hline Dominican Republic & Latin America (LATAM) & 1 & $\$ 53,976$ & $\$ 51,800$ to $\$ 54,040$ \\
\hline Ecuador & Latin America (LATAM) & 1 & $\$ 36,238$ & $\$ 36,010$ to $\$ 36,460$ \\
\hline Gabon & Africa/Middle East & 1 & $\$ 68,943$ & $\$ 67,410$ to $\$ 69,210$ \\
\hline Namibia & Africa/Middle East & 1 & $\$ 49,909$ & $\$ 49,130$ to $\$ 50,110$ \\
\hline Peru & Latin America (LATAM) & 1 & $\$ 52,524$ & $\$ 51,740$ to $\$ 52,860$ \\
\hline
\end{tabular}

Table 3 Aggregate costs by region and TKI count

\begin{tabular}{|c|c|c|c|c|c|}
\hline Region & 5-year cost (\%) & TKI access & First year fix & First year var & 5 -year cost \\
\hline South Asia & $\$ 15,084,618(52 \%)$ & 5 & $\$ 540,850$ & $\$ 909,370$ & $\$ 6,438,176$ \\
\hline Africa/Middle East & $\$ 7,284,210(25 \%)$ & 4 & $\$ 323,610$ & $\$ 865,947$ & $\$ 5,723,011$ \\
\hline Europe/Central Asia & $\$ 2,954,959(10 \%)$ & 3 & $\$ 579,310$ & $\$ 3,031,829$ & $\$ 14,493,223$ \\
\hline Asia Pacific & $\$ 1,938,714(7 \%)$ & 2 & $\$ 188,510$ & $\$ 308,242$ & $\$ 2,227,083$ \\
\hline Latin America (LATAM) & $\$ 1,880,582(6 \%)$ & 1 & $\$ 161,580$ & $\$ 32,770$ & $\$ 261,590$ \\
\hline Total & $\$ 29,143,083$ & Total & $\$ 1,740,000$ & $\$ 5,148,158$ & $\$ 29,143,083$ \\
\hline
\end{tabular}

instruments to cover all countries would be inefficient, likely resulting in idle instruments due to the lack of resources to procure sufficient amounts of the BCR-ABL assay. In order to remove the PCR monitoring barrier and improve clinical care for patients with CML, it will be essential to adopt a comprehensive plan to engage partners who are vested in strengthening health systems supporting cancer care in LMIC. Drug manufacturers, non-governmental organizations, governments, interest groups, and/or philanthropists may find value in aiding specific countries to increase PCR capacity. Since the oncology portfolio for the GeneXpert ${ }^{\circledR}$ system includes testing for breast cancer, bladder cancer, and HPV, this multi-sector approach requires collaboration and coordination among agencies and organizations within LMICs to maximize partner investments and avoid the inefficiency of duplicated efforts. Moreover, investment in PCR monitoring in these countries might lead to strengthening health systems so that physicians and specialized treatment centers are able to respond to the needs of a more diverse patient population.

Nearly $90 \%$ of the overall gap in PCR monitoring capacity for CML is in the procurement of cartridges. Even at a preferential (below market) cost of $\$ 50$, singletest cartridges are still costly, particularly in resourcepoor settings. Although CML is a relatively rare disease worldwide, a buy-down approach consisting of an upfront, pre-purchase of Xpert ${ }^{\circledR}$ cartridges at higher volumes and reduced prices might further reduce costs. A similar approach was employed by the Bill and Melinda Gates Foundation, the United States President's Emergency Plan for AIDS Relief (PEPFAR), the United States Agency for International Development (USAID), and Unitaid [10, 11].

A limitation of our analysis is that we used estimates of the burden of disease by country based on the number of CML patients enrolled in GIPAP and Max Access Solutions from 2002 to 2017. This is an underestimate of the true gap based on burden of disease estimates obtained from epidemiological data [9]. There are significant numbers of patients that did not enter these programs because of access limitations due to geography, culture, cost, and other social determinants of health. Future analyses might consider this epidemiological burden, combined with estimates of the gap in diagnostic and treatment (with TKIs) capacity. Ongoing research in this area can also examine to what degree the gap in CML treatment capacity is a subset of a general prevailing gap in health system capacity related to infrastructure and personnel that may not be amenable to targeted solutions such as increased access to GeneXpert ${ }^{\circledR}$ machines and supplies. 
$\$ 30,000,000$

\section{$\$ 25,000,000$}

$\$ 20,000,000$

$\$ 15,000,000$

$\$ 10,000,000$

$\$ 5,000,000$

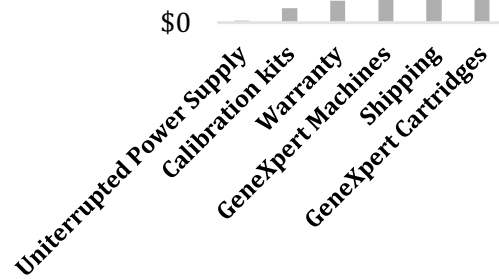

Fig. 1 Costs by resource

Removing the gap in PCR monitoring capacity for CML can help improve health outcomes. While quantifying the health outcomes benefit was beyond the scope of this analysis, we expect that removing the gap in PCR diagnostic capacity would increase the demand for CML care, both within the access initiatives available through The Max Foundation and in general health services. Future studies might consider quantifying the health outcomes benefits in terms of quality-adjusted life-years gained or disability-adjusted life-years averted using state-transition (Markov) models as in multiple economic evaluations of TKIs [12-16].
NCCN and ELN monitoring guidelines are based on monitoring intervals used in TKI clinical trials, and thus it is not clear what optimal testing intervals actually are. For example, optimal design might include how long a patient has been on a TKI, and the kinetics of their BCRABL1 decline, rather than a simplistic every 3 months rule. Thus, revisiting guidelines with limited resources in mind may allow for a CML monitoring scheduled tailored to the LMIC setting, optimizing the benefits of frequent monitoring without sacrificing patient outcomes.

\section{Conclusions}

By treating thousands of patients since 2001 in eligible countries, The Max Foundation's access programs have added thousands of life-years and improved the quality of life of thousands of people living with CML. Removing the 5-year gap in PCR monitoring capacity for CML in these countries will require the mobilization of significant resources and will likely lead to better treatment outcomes and reduced treatment costs through optimization of treatment, discontinuation of therapy in appropriate patients, and facilitation of clinical research.

\section{Acknowledgements \\ Not applicable.}

\section{Authors' contributions}

SR, PG-G, and JBB conceived of the study. SR and JBB designed the study, developed the model, and performed the analysis. SR and JBB developed the first version of the manuscript. SR, PG-G, JR, IU, and JBB further developed the manuscript and contributed important intellectual content to the final version. All authors read and approved the final manuscript.

\section{Funding}

The Max Foundation funded this work through a grant to the University of Washington. An annual breakdown of The Max Foundation's revenue can be found at https://www.themaxfoundation.org/about-us/financials/. In the year 2019, The Max Foundation was funded as follows: 97\%, in-kind pharmaceutical contributions; and 3\%, contributions, grants, and sponsorships. A list of The Max Foundation's partners can be found at https://www.themaxfoundatio n.org/partners/. Corporate partners included AA Pharmacy, Amgen, Asuragen, Bourne Partners, Bristol Myers Squib, Cepheid, Incyte, Novartis, Pfizer, Tanner Pharma Group, and Takeda. The Max Foundation participated in the conception of the study, provided data to parameterize the model and participated in writing the manuscript.

\section{Availability of data and materials}

The datasets during and/or analysed during the current study, including modeling framework, available from the corresponding author on reasonable request.

\section{Declarations}

Ethics approval and consent to participate Not applicable.

\section{Consent for publication}

Not applicable.

\section{Competing interests}

$\mathrm{SR}$, JPR, and JBB declare that they have no competing interests. PG-G, AKN, and IU are employees of The Max Foundation which provided funding for the research. 


\section{Author details}

${ }^{1}$ Department of Epidemiology, School of Public Health, University of Washington, Seattle, USA. ${ }^{2}$ The Max Foundation, Seattle, WA, USA. ${ }^{3}$ Fred Hutchinson Cancer Research Center, Seattle, WA, USA. ${ }^{4}$ Global Medicines Program, Department of Global Health, School of Public Health, University of Washington, Seattle, USA. ${ }^{5}$ The Comparative Health Outcomes, Policy, and Economics (CHOICE) Institute, University of Washington, Seattle, USA.

Received: 21 August 2020 Accepted: 3 March 2021

Published online: 12 March 2021

\section{References}

1. Saussele S, Krauss MP, Hehlmann R, Lauseker M, Proetel U, Kalmanti L, Hanfstein B, Fabarius A, Kraemer D, Berdel WE, et al. Impact of comorbidities on overall survival in patients with chronic myeloid leukemia: results of the randomized CML study IV. Blood. 2015;126:42-9.

2. Baccarani M, Deininger MW, Rosti G, Hochhaus A, Soverini S, Apperley JF, Cervantes F, Clark RE, Cortes JE, Guilhot F, et al. European LeukemiaNet recommendations for the management of chronic myeloid leukemia: 2013. Blood. 2013;122:872-84.

3. Radich JP, Deininger M, Abboud CN, Altman JK, Berman E, Bhatia R, Bhatnagar B, Curtin P, DeAngelo DJ, Gotlib J, et al. Chronic myeloid leukemia, version 1.2019, NCCN clinical practice guidelines in oncology. J Natl Compr Canc Netw. 2018;16:1108-35.

4. Winn-Deen ES, Helton B, Van Atta R, Wong W, Peralta J, Wang J, Tsongalis GJ, Belloni D, Chan D, Eshleman JR, et al. Development of an integrated assay for detection of BCR-ABL RNA. Clin Chem. 2007:53:1593-600.

5. Stevens WS, Scott L, Noble L. Gous N. Dheda K: Impact of the GeneXpert MTB/RIF Technology on Tuberculosis Control. Microbiol Spectr; 2017.10.1128/microbiolspec.TBTB2-0040-2016.

6. Wexler C, Nazir N, Maloba M, Brown M, Goggin K, Gautney B, Maosa N, Babu S, Muchoki E, Mabachi N, et al. Programmatic evaluation of feasibility and efficiency of at birth and 6-week, point of care HIV testing in Kenyan infant. PLoS ONE. 2020;15:e0240621.

7. Garcia-Gonzalez P, Boultbee P, Epstein D. Novel humanitarian aid program: the glivec international patient assistance program—lessons learned from providing access to breakthrough targeted oncology treatment in low- and middle-income countries. J Glob Oncol. 2015;1:37-45.
8. Novartis and The Max Foundation transform pioneering cancer access program for people in lower-income countries. https://www.novartis. $\mathrm{com} /$ news/media-releases/novartis-and-max-foundation-transformpioneering-cancer-access-program-people. Accessed 23 Jan 2018.

9. Dong Y, Shi O, Zeng Q, Lu X, Wang W, Li Y, Wang Q. Leukemia incidence trends at the global, regional, and national level between 1990 and 2017. Exp Hematol Oncol. 2020;9:14.

10. Stop TB Department (2012) Buy-down agreement to reduce cost of Xpert MTB/RIF cartridges by $40 \%$ for high-burden countries. http://www.stopt b.org/wg/new_diagnostics/assets/documents/News_XpertPrice_21Aug 12.pdf. Accessed 24 Jan 2018.

11. Public-Private Partnership Announces Immediate 40 Percent Cost Reduction for Rapid TB Test | The Bill \& Melinda Gates Foundation. Press Release. August 6th 2012. https://www.gatesfoundation.org/Media-Center/Press -Releases/2012/08/PublicPrivate-Partnership-Announces-Immediate-40Percent-Cost-Reduction-for-Rapid-TB-Test. Accessed 23 Jan 2019.

12. Li N, Zheng B, Cai HF, Yang J, Luo XF, Weng LZ, Zhan FM, Liu MB. Cost effectiveness of imatinib, dasatinib, and nilotinib as first-line treatment for chronic-phase chronic myeloid leukemia in China. Clin Drug Investig. 2018;38:79-86.

13. Kulpeng W, Sompitak S, Jootar S, Chansung K, Teerawattananon Y. Costutility analysis of dasatinib and nilotinib in patients with chronic myeloid leukemia refractory to first-line treatment with imatinib in Thailand. Clin Ther. 2014;36:534-43.

14. Wu B, Liu M, LiT, Lin H, Zhong H. An economic analysis of high-dose imatinib, dasatinib, and nilotinib for imatinib-resistant chronic phase chronic myeloid leukemia in China: a CHEERS-compliant article. Medicine. 2017;96:e7445.

15. Whalen J, Stillman I, Ambavane A, Felber E, Makenbaeva D, Bolinder B. Cost-effectiveness analysis of second-line tyrosine kinase inhibitor treatment for chronic myelogenous leukemia. J Med Econ. 2016;19:445-61.

16. Romero M, Chávez D, De Los RM, Alvis-Guzmán N. Cost-effectiveness of nilotinib, dasatinib and imatinib as first-line treatment for chronic myeloid leukemia in Colombia, 2012. Biomedica. 2014;34:48-59.

\section{Publisher's Note}

Springer Nature remains neutral with regard to jurisdictional claims in published maps and institutional affiliations.
Ready to submit your research? Choose BMC and benefit from:

- fast, convenient online submission

- thorough peer review by experienced researchers in your field

- rapid publication on acceptance

- support for research data, including large and complex data types

- gold Open Access which fosters wider collaboration and increased citations

- maximum visibility for your research: over $100 \mathrm{M}$ website views per year

At $\mathrm{BMC}$, research is always in progress.

Learn more biomedcentral.com/submissions 